\title{
On what a distinctively political normativity is
}

Article

Accepted Version

Jubb, R. (2019) On what a distinctively political normativity is. Political Studies Review, 17 (4). pp. 360-369. ISSN 1478-9302 doi: https://doi.org/10.1177/1478929919832251 Available at https://centaur.reading.ac.uk/81887/

It is advisable to refer to the publisher's version if you intend to cite from the work. See Guidance on citing.

To link to this article DOI: http://dx.doi.org/10.1177/1478929919832251

Publisher: SAGE

All outputs in CentAUR are protected by Intellectual Property Rights law, including copyright law. Copyright and IPR is retained by the creators or other copyright holders. Terms and conditions for use of this material are defined in the End User Agreement.

\section{www.reading.ac.uk/centaur}

\section{CentAUR}

Central Archive at the University of Reading

Reading's research outputs online 
On What a Distinctively Political Normativity Is ${ }^{1}$

Normative political theory hopes to provide political prescriptions. It aims to describe what, for example, a commitment to democracy properly involves or which principles govern and so constitute a just system of property rights. Insofar as we are not merely interested in politics as an intriguing game but come to it with views about what democracy is, the rightful place of socio-economic equality in our political economy or any number of other animating convictions, we have an interest in seeing the task of normative political theory, which can help us think through them, carried out properly. Unless it is carried out properly, it may be difficult to adequately capture the concerns underlying work on, for instance, participation and responsiveness in democratic political systems (Sabl, 2016). In this sense, the recent growth in interest in normative political theory in methodological questions, and particularly about the relation of its prescriptions to the messy and unsatisfactory political reality with which we are familiar, ought to be of interest to scholars working across the academic discipline of politics. Is normative political theory being carried out properly, and what changes might we expect if it is not?

One of the recent methodological debates, initiated for many of its participants by a posthumous collection of Bernard Williams' work on political philosophy (Williams, 2005), has been around what Williams there called realism. Realists aim to defend the importance of "distinctively political thought" as opposed to the applied ethics they believe characterizes much contemporary political theory and causes it to misunderstand and make mistakes about its subject matter (Williams, 2005, p. 2). Matt Sleat's recent edited collection, Politics Recovered, gives a sense of the range and significance of work which can be grouped under this commitment, stretching from Mark Philp's exploration of the concept of corruption to Alison McQueen's linkage of realism in international relations to the political theory variety (2018). Understandably, scholars working in normative political theory, conventionally conceived, have attempted to respond to the realist critique of their work, which has in turn prompted realist counter-responses (Erman \& Moller, 2015; Erman \& Moller, 2015; Jubb \& Rossi, 2015; Jubb \& Rossi, 2015). These exchanges have often seemed like they involve varying degrees of mutual misunderstanding and associated acrimony, and so in that sense Jonathan Leader Maynard and Alex Worsnip's keenness to avoid the two sides talking past each other in their recent piece in Ethics, 'Is There a Distinctively Political Normativity?', is welcome (2018, p. 4ff).

\footnotetext{
${ }^{1}$ Alice Baderin, Ed Hall, Enzo Rossi, Paul Sagar and Matt Sleat all provided me very helpful comments on this paper. I would also like to thank two anonymous referees for their comments and Justin Fisher for his clear editorial guidance.
} 
Leader Maynard and Worsnip still suggest realism is mistaken, however constructive they at least intended to be, taking its denial of normative political theory's "ineliminable roots in morality" to be an error (2018, p. 25). They make this suggestion by criticizing five arguments realists have made for the distinctive character of political normativity, and so try to disarm at least one of the ways in which realists criticize contemporary political theory's supposed reliance on ethics and moral philosophy. However, there are two problems I identify here with Leader Maynard and Worsnip's account. First, I do not think that their criticisms of the five arguments they discuss in the end succeed, and I will begin the remainder of this response by outlining where I think those criticisms fail. However, the strategy Leader Maynard and Worsnip adopt is not in the end unsatisfactory because it is, as it were, poorly executed; it seems to me also to misconceive the challenge its opponent presents and in that sense question the possibility of the kind of engagement for which they claim to hope. In that sense, my aim here is not even mainly to respond to the arguments Leader Maynard and Worsnip present, though I take that to be important too. My aim is to suggest that thinking about what is at issue in the way they do is, and is likely to continue to be, unproductive.

Realism is most sensibly understood as a hostility to a way of doing political philosophy and theory, and much of the power it has lies in the alternatives it proposes. This is particularly so given the centrality of individual agency and so particularity and context in realism. It is not an accident that the posthumous collection of Williams' political work that sparked contemporary interest in realism is called In the Beginning was the Deed. The challenge realism presents to moralism is unlikely to be settled by treating it as an attempt to demonstrate, in analytically rigorous terms, that moralism makes conceptual mistakes. Although such a strategy is problematic partly because it tries to assess realism on moralism's terms, that is presumably inevitable to some degree. Instead, attempting to adjudicate between realism and moralism at the level of precise and perfectly generalizable methodological prescriptions is in the end unsatisfactory because there is not sufficient common ground to agree on the prescriptions at stake, their meaning or their connections to each other. Talking past each other is inevitable if realism is understood as that kind of challenge, not just because that is not how realists conceive of the challenge, but because it is difficult to see how there can be a shared characterization of what is at stake at that level. Rather than adopting Leader Maynard and Worsnip's strategy, it would be better instead to consider the concrete attempts to describe, assess and offer guidance about politics that realists have made. To this end, as well as observing how Leader Maynard and Worsnip's strategy seems inevitably to struggle, I will finish this piece by describing some of the work on political vices done by realists. 
Leader Maynard and Worsnip spend almost a quarter of their paper discussing what is at stake in disputes over whether "political theory is something like applied morality" (3). Parts of that discussion seem to me unsatisfactory. For example, for all Rawls' insistence on political philosophy as a distinct category, his view is not standard and contra Leader Maynard and Worsnip much contemporary political philosophy does think of itself as "private morality writ large" (4 (italics suppressed)). This is precisely the point of not only of G. A. Cohen's attacks on Rawls, but also of his positive work, exemplified in his argument that socialism is the best way to run society because it is the best way to run camping trips (2008, p. 1; 2009). Equally, revisionist just war theory centrally depends on treating restrictions on military violence as continuous with those that apply between private individuals, and so war as a somehow collectivized exercise of individual self-defence (Rodin, 2002). Relatedly, defining the realist view as "that political principles are of a different, non-moral normative kind altogether" (5 (italics suppressed)), as Leader Maynard and Worsnip do, appears to ignore, for example, Williams' description of his basic legitimation demand as distinct from moralist approaches because it arises from within politics and so does "not represent a morality which is prior to politics" (2005, p. 5). Like many other realists, Williams here does not require that normativity avoid morality altogether, but that prescriptions are in some way filtered through or aligned to politics as a category (Sleat, 2016, p. 253). This would still leave political normativity distinct from moral normativity, in the sense that the weight, direction and relevance of different considerations would all systematically be altered by politics' constitutive features.

In the end, Leader Maynard and Worsnip favour construing the distinction between political and moral normativity not on the basis of how prescriptions respond to the features of a particular domain, but on the basis of the kind of ought involved. They illustrate this way of drawing that distinction by reference to Stephen Darwall's characterization of morality as specifically concerned with resentment, in which the moral ought becomes that ought whose breach warrants resentment (5). Although Leader Maynard and Worsnip do not endorse Darwall's conception of morality, which would be problematic given the role resentment plays in several prominent realist accounts (Williams, 2005, pp. 75-96), or indeed any other, this causes them other difficulties. Without a firm commitment to some specific way of understanding the relevant distinction between moral and political normativity, the criteria of success for their arguments necessarily remain ambiguous. What does it take to show that prescriptions are in the end moral, if it is unclear what constitutes either distinctively moral or, contrastingly, distinctively political prescriptions? Given that this terrain is, almost inevitably, contested and that disentangling the substantive and semantic disagreements involved in that dispute is likely to be extremely difficult without teasing them out through their use in particular contexts, it is unsurprising that the strategy Leader Maynard and Worsnip adopt of 
seeking to resolve this debate at a completely general conceptual level struggles. Stating the terms on which their solution depends without prejudging or obscuring substantive questions may well be impossible, and the more they do so, the more a supposed solution will miss the point.

The five arguments for a distinctive political normativity Leader Maynard and Worsnip try to reject are that the truth of a moral claim does not make it "legitimate to enforce politically" (8); that because "there is deep disagreement over moral claims, morality cannot resolve what to do" politically (9); that since "political normativity should be understood in a constructivist manner, while moral normativity should not", there is a metanormative difference between the two (14: italics suppressed); that "the differences in the content of private morality and political normativity are so [great] that the two cannot plausibly be regarded as belonging to the same... overarching category" (16-17: italics suppressed); and that Williams' basic legitimation demand "is a demand from within politics itself, and thus represents a distinctively political normativity" (20). The arguments with which Leader Maynard and Worsnip try to reject these five realist claims are all, in one way or another, problematic, I think even on their own terms, and I will go on to try briefly to show why. At this level of generality, though, questions of reasonable interpretation and implication are all themselves rather abstract and so similarly subject to interpretative and implicative controversy. While perhaps not all the difficulties into which Leader Maynard and Worsnip fall result from their approach to the question, the persistence of these problems should be indicative. Where methodological questions and so how to use and understand terms are at stake, abstract general arguments are often not the best way to attempt to resolve more concrete disputes.

Leader Maynard and Worsnip do not see the first realist argument as "the core realist rationale" but something "which occasionally seems implicit in realist writings" (8). This argument moves from limits to the political enforceability of even valid moral claims to a distinctive political normativity. Politics cannot be applied morality because the validity of a moral claim does not show that it has any implications for the grounds on which people may be coerced. As Leader Maynard and Worsnip point out, many supposedly moralist philosophers and theorists admit that there are limits to the political enforceability of valid moral claims; they just see those limits as moral, as "a special case of the more general point... that actor A morally ought to do action X, while... actor B morally ought not to force actor A to do action X" (9). Realists who claim that moralism involves the denial of limits on the enforceability of moral claims are then relying on "inaccurate caricatures" (8). However, the familiarity of both the general point and least some of its special cases suggest that realists are aware of them. That in turn suggests that they are unlikely to have made an argument whose success depends on them being unaware of 
either. Indeed, neither of the quotations from realists Leader Maynard and Worsnip use straightforwardly support the idea that realists move from a claim about the importance of limits on the enforcement of morality to a claim about political normativity. Where they quote Enzo Rossi and Robert Jubb accusing moralists of demanding the enforcement of private morality, we were reporting a conclusion we had argued followed from rejecting a distinction between politics and sheer domination (Jubb \& Rossi, 2015, p. 4). The other quotation they provide, from Edward Hall about discounting objections from fellow citizens who are only mistaken interlocutors, relates to Williams' attack on a specific way of theorizing liberty (Hall, 2017, p. 294). This seems an unfortunate reversion to the norm of responding to realists by inaccurately attributing obviously implausible views to them, and so in tension with Leader Maynard and Worsnip's aspiration to move beyond acrimony.

The second argument Leader Maynard and Worsnip consider moves to a distinctive political normativity from a claim about the centrality of moral disagreement to politics. Politics cannot be governed by morality because politics is only necessary insofar as we fail to agree what, morally, we ought to do. This argument fails, they claim, because "it rests on a misconstrual of the role that moralists want their principles to play". Moralists are not hoping to settle political questions with their prescriptions, but instead to evaluate "political processes and their outcomes in terms of their justice, rightness and so on" (11). Although Leader Maynard and Worsnip go on to consider various further questions they see as related to that distinction between de facto and normative resolutions, like what role an error theory might play, the distinction seems to miss realists' basic point here. I might evaluate a practice, institution, object, event or relationship from any number of perspectives. That something is, in its own terms, a coherent evaluation does not tell us anything about the relevance of that evaluation to how what it evaluates ought to be treated. An evaluation of the British Library's collection in terms of each member's individual resale value, even as books and manuscripts rather than as, say, kindling, would not give us conclusive reasons to do anything. Part of its point is that it is a collection. Similarly, there is an obvious reason why straightforwardly moral evaluations of political processes and outcomes are not clearly relevant to those processes and outcomes. Insofar as the evaluations assume, for example, high levels of moral agreement and compliance they are not evaluations of them as solutions to familiar political problems. Familiar political problems are in part constituted by the absence of high levels of moral agreement and compliance, and so straightforwardly moral evaluations are instead evaluations of situations where political problems exist, if at all, quite differently.

Participants in disputes about the currency of egalitarian justice, for example, often insist that questions about implementing their favoured currency are irrelevant to its justification. For 
example, that someone resents being questioned about their level of happiness does not impugn using happiness as a way of measuring whether they have been treated appropriately equally to others (Cohen, 1989, p. 910). Yet resentment of this sort is an inevitable feature of any attempt to distribute happiness equally in the real world. Does equality so conceived then require a proxy for happiness, and if so, which? Should that proxy take into account resentments that might be produced by its use, and in particular its use in contrast to the proper measure of happiness on which the just might rightly insist? The insistence on ignoring central features of political life, like predictable if morally disappointing resentment at intrusive questioning by agents of the state, leaves the view unable to say much about what actually ought to be done. How evaluations of this sort are supposed to guide actors faced with problems which are necessarily absent in them is quite opaque (Tomlin, 2012; Jubb, 2016). If anything, it is moral normativity which is threatened by Leader Maynard and Worsnip's distinction, since the retreat into evaluation threatens to strip moral claims of their prescriptive power and political relevance.

Leader Maynard and Worsnip's attempts to turn their third and fourth realist argument both rely on their rather demanding account of what a distinctively political normativity involves. The third realist argument is that political normativity is distinct from moral normativity because it is constructed, whereas moral normativity is not. This metanormative difference would distinguish the two forms of normativity. As Leader Maynard and Worsnip note, there are a number of difficulties in holding that two seemingly closely-linked forms of normativity have such different foundations, particularly given many realists' scepticism about morality (14ff). What they do not explain though is why the metanormative difference has to be between different kinds of foundations rather than between different kinds of constructions. Epistemic normativity could well be, if constructed, constructed quite differently from moral normativity, if moral normativity is constructed. The features and capacities we have as agents relevant to the construction are likely to be quite distinct, and to shape the process of construction accordingly. How we ought to relate to our capacities to form beliefs is likely to be very different from how we ought to relate to each other, for example, as agents with a particular set of mutual vulnerabilities, not just in terms of the content of the relevant prescriptions but in their underlying structure and rationale. The idea of justification may well not just impose a different set of requirements, but play a different role, for instance. The same could equally be true of any difference between constructed moral and political normativity. It is not obviously implausible to think of such differences as metanormative, or clear how a sufficiently sharp boundary could be drawn to exclude or include them without begging the question, or that what any differences are called makes much difference as long as they are there. 
The fourth argument that Leader Maynard and Worsnip discuss claims that there are such significant first-order normative differences between moral and political prescriptions that they must be seen as different kinds of normativity. However, even if politics is "systematically more consequentialist" than private morality, even if there are distinctive political virtues, that does not show that those demands cannot be captured under an overarching moral principle or that the virtues should not be used only for morally sanctioned ends (16, quoting (Philp, 2010, pp. 474-475); 17ff). Here, again, we are left with the question of what counts as distinctive. Science as a practice is constituted in part by various norms: what counts as evidence for and against a proposition, how that evidence is to be weighted and combined coming to a conclusion, what should and shouldn't be said publicly, who counts as a member of the relevant public, and so on. Many of these norms relate, often as specifications of more general prescriptions, to epistemic norms more broadly. That does not seem to me to support the claim that there is no distinctive scientific normativity. Whether there is a distinctive scientific normativity depends, for example, in part on how useful it is to treat the norms of science as comprising a separate field, not whether, in principle, they could be reduced to their often rather distant foundations in the norms of a pre-existing field. Equally, realists, including Philp, do not think it is useful to understand political philosophy as continuous with moral philosophy. That it may be possible to offer foundations for the former in the latter does not show there is nothing distinctive about it. The fifth and final argument Leader Maynard and Worsnip consider involves treating the achievement of a certain kind of legitimacy as definitive of politics. On this account, politics distinguishes right from might by requiring political authorities to offer an explanation of their authority to their subjects. Since neither the requirements of or for the explanation are fixed outside of politics, political normativity is distinct. The most basic question of politics is asked for and answered with reasons themselves drawn from politics. Leader Maynard and Worsnip find this argument problematic because, at best, even assuming problems with the definition of politics can be overcome, ${ }^{2}$ this does not provide a good reason for engaging in politics in the first place. The normative question has just been pushed "back from "why, in a given situation, should we practice politics in one way rather than another?" to "why, in a given situation, should we practice politics, rather than something else?"' (22). Just as we can ask why we should employ people rather than force them to work, we can ask why we should do politics, rather than organize our collective life in some other, as yet unspecified way, or perhaps eliminate it all together. Leader Maynard and Worsnip claim this undermines the

\footnotetext{
${ }^{2}$ As Edward Hall has shown, Bernard Williams' version of this view, focused on his Basic Legitimation Demand, does not require that the explanation succeeds for all those to whom it is offered (Hall, 2015, p. 473ff). In that sense, what matters for Williams is that the BLD is raised, not, as Leader Maynard and Worsnip would have it, satisfied (20). This makes the definition thinner and so less problematic than they suppose.
} 
distinctiveness of political normativity in the same way and to the same extent as the idea that there are overarching moral principles which capture the greater consequentialism of political life. That political principles and questions can, in the end, be reduced to a different sort of principle or question supposedly shows that there are no distinctively political principles or questions, independently of whether there are good reasons to treat political principles and questions as distinctive. At the very least, this is a kind of reductionist foundationalism that requires independent support.

The five realist arguments Leader Maynard and Worsnip attempt to rebut then may well survive their attacks. This, I suggest, is because there are underlying commitments, assumptions and habits of thought which structure all of our engagements with debates between realists and moralists. It is very difficult to get clear about how all those factors shape the debate, never mind about how we ought to try to understand or interpret them in that context. Political philosophers and theorists seemingly cannot agree what counts as a distinctive political normativity, let alone what would be conclusive evidence in favour of or against it. At a general conceptual level, it is and seemingly always will be very difficult to resolve disputes over realism and moralism. It would be better to move to consider the distinctiveness of political thought from another angle.

Realists tend to emphasize, when suggesting that getting to grips with politics requires distinctive modes of thought, that politics is structured by relationships of power. Enforcement of collectively-binding decisions, particularly on those who disagree with them, and the practices and institutions that go with it are necessary parts of politics. This is the one of the two premises from which Williams's Basic Legitimation Demand arises, for instance. Unless might is being exercised, there is no question about what might legitimate it. This focus on power should be familiar to anyone who has been following debates between realists and moralists. What may be less clear is the range and form of questions this opens. Taking seriously the reality of power in political relationships means thinking through its effects, both on those over whom it is exercised and on those who exercise it. This is what Bernard Williams means to draw attention to when he says that what a political decision "immediately announces" is that one side "have lost" and not that they are "morally wrong, or indeed, wrong at all" (Williams, 2005, p. 13). Political decisions have practical rather than immediately theoretical consequences. Various resentments and refusals may follow from them and they, along with the opportunities such decisions also create, need to be thought through and understood and assessed.

Consider for example Judith Shklar's Ordinary Vices. There, Shklar tried to do what she took "to be the job of political theory: to make our conversations and convictions about our society more 
complete and coherent and to review critically the judgments we ordinarily make and the possibilities we see" (Shklar, 1984, p. 226). Rather than a focus on how particular choices ought to be made or the values instantiated by creating a particular institution, Shklar sought to do that by exploring five everyday vices and how those negative ideals of character might relate to each other, to the rest of an individual's or a group's character and to social and political institutions and the shared goods they create and sustain. By arguing that we should put cruelty first, she hoped to show that we should adopt what she called there and elsewhere the liberalism of fear. Putting cruelty first and the liberalism of fear go together for Shklar because both have the courage to choose "self-restraining tolerance" over promises of virtue that will in the end necessitate "military and moral repression and violence" (1984, p. 5). As this suggests, the distinctive point of the liberalism of fear is its central focus on the pathologies of power and its exercise. As Shklar put it, for the liberalism of fear "the basic units of political life are not discursive and reflective persons, nor friends and enemies, nor patriotic soldier-citizens, nor energetic litigants, but the weak and the powerful" (1989, p. 27).

Certainly one might disagree with the horror Shklar clearly feels at the effects of cruelty, just as one might question the links she draws between it and the cautious suspicion, particularly about any claims to singular or distinctive virtue, that makes up the liberalism of fear as much as any set of institutional prescriptions. Perhaps cruelty is not always as awful or as inevitably associated with projects for ensuring rule by the most virtuous, just or enlightened as Shklar feared. Some form of individual and collective moral perfection may be achievable without trying and failing to eliminate disagreements that are "both ineluctable and tolerable, and entirely necessary for any degree of freedom" (Shklar, 1984, p. 227). Loathing hypocrisy, most particularly in oneself, might not be quite the invitation to a destructive hatred of humankind Shklar supposed. Maybe puritanical moral critics are wrong to claim we are terrible backsliding hypocrites, just as we may be wrong to suspect that their disapproval conceals and is significantly motivated by an awareness of the hollowness of their own professions of rectitude. The choice Shklar in the end offers between the rage of those disgusted by the cheap betrayals of liberal and representative politics and the society it creates, and the more impersonal, resigned misanthropy of those who reconcile themselves to them, fearing cruelty more, is, after all, rather stark.

Those though are the sorts of claims that Ordinary Vices makes. There, Shklar does not make a series of claims about the abstract methodological injunctions which justify treating political normativity as (sufficiently) distinct from moral normativity with which we might engage with in the way that Leader Maynard and Worsnip seek. She does not use that mode of reasoning because she prefers a more discursive, allusive method, often leaning on stories of one sort and 
another, in order to get at the "subtle interactions", the "ritual, display, social exchanging and acting out in the public arena", that interest it (1984, p. 231). That does not mean those relying on a philosophical style of "arguments and counterarguments designed to avoid contradiction and exception" that Shklar consciously avoids gain nothing from her work, either in Ordinary Vices or more broadly (1984, p. 6). Shklar aims to think through the broader effects, the phenomenology and slow accumulation of new habits and patterns of thought, not easily captured by "general laws or models... necessary for assessing the rational consistency and consequences of specific decisions or policy choices" (1984, p. 231). These effects, generated by the enforcement (or not) of specific decisions and policy choices as they ramify through a system, are central to our experience of our social and political lives and so to their coherence, stability and sustainability.

What a society's members can sensibly be expected to think of it and what can sensibly be said in response to them has to matter to political theory and philosophy. It mattered to John Rawls, widely regarded as the central influence on the sub-discipline's current form and practice. It was crucial to his argument against utilitarianism through the requirements of finality and publicity even in A Theory of Justice (1971, p. 175ff). The characters a society creates and with which it can live are plausibly best explored as Shklar tries. Her claims, for example, can be contrasted with G. A. Cohen's claims about the greed and fear that allegedly typically predominate in market transactions (2009, p. 40). As Williams observed, this "extraordinary" view "leaves out entirely one of the most significant motives expressed in markets: mutual advantage". No-one supposes that either a small shopkeeper or her customers are primarily driven by greed or fear in their interactions, and Cohen's view can only be based on "a model of some markets rather than others, in particular of a labour market based on unequal income" (1997, p. 56). As one of the standard-bearers of abstraction and freeing political and moral theory and philosophy from awkward facts (2003), the implausibility of Cohen's claims about ordinary vices are indicative of the contrasting strengths of Shklar's method and its focus on how power plays out through a set of practices and institutions. Shklar once described the liberalism of fear using Emerson's contrast between the party of hope and the party of memory (1989, p. 26), and both the liberalism of fear and her work more broadly draw on history in ways than is, or perhaps should be, common in contemporary moral and political philosophy and theory. Those so completely trained as members of a party of hope they are unaware of the party of memory may find her work and that of other realists difficult to grasp, and be tempted to approach it with hopeful methods. They will though be missing its point, as I hope I have shown here. 
Bibliography

Cohen, G. A. (1989). On the Currency of Egalitarian Justice. Ethics, 99(4), 906-944.

Cohen, G. A. (2003). Facts and Principles. Philosophy and Public Affairs, 31(3), 211-245.

Cohen, G. A. (2008). Rescuing Justice and Equality. Cambridge: Harvard University Press.

Cohen, G. A. (2009). Why Not Socialism. Princeton: Princeton University Press.

Erman, E., \& Moller, N. (2015). Political Legitimacy in the Real Normative World. British Journal of Political Science, 45(1), 215-233.

Erman, E., \& Moller, N. (2015). Why Political Realists Should Not Be Afraid of Moral Values. Journal of Philosophical Research, 40, 459-464.

Farrelly, C. (2007). Justice in Ideal Theory: A Refutation. Political Studies, 55(4), 844-864.

Hall, E. (2015). Bernard Williams and the Basic Legitimation Demand: A Defence. Political Studies, 63(2), 466-480.

Hall, E. (2017). How to Do Realistic Political Theory (And Why You Might Want to). European Journal of Political Theory, 16(3), 283-303.

Jubb, R. (2016). Norms, Evaluations, and Ideal and Nonideal Theory. Social Philosophy and Policy, 33(1-2), 393-412.

Jubb, R., \& Rossi, E. (2015). Political Norms and Moral Values. Journal of Philosophical Research, $40,455-458$.

Jubb, R., \& Rossi, E. (2015). Why Moralists Should Be Afraid of Political Values: A Rejoinder. Journal of Philosophical Research, 40, 465-468.

Maynard, J. L., \& Worsnip, A. (2018). Is There a Distinctively Political Normativity. Ethics, 128(4), 756-787.

Mills, C. (2005). "Ideal Theory" as Ideology. Hypatia, 20(3), 165-184.

Philp, M. (2010). What Is to Be Done? Political Theory and Political Realism. European Journal of Political Theory, 9(4), 466-484.

Rawls, J. (1971). A Theory of Justice. Cambridge: Harvard University Press.

Rodin, D. (2002). War and Self-Defense. Oxford: Oxford University Press.

Sabl, A. (2016). The Two Cultures of Democratic Theory: Responsiveness, Democratic Quality, and the Empirical-Normative Divide. Perspectives on Politics, 13(2), 345-365.

Sen, A. (2006). What Do We Want from a Theory of Justice. Journal of Philosophy, 103(5), 215238.

Shklar, J. N. (1984). Ordinary Vices. Cambridge: Harvard University Press.

Shklar, J. N. (1989). The Liberalism of Fear. In N. L. Rosenblum, Liberalism and the Moral Life (pp. 21-38). Cambridge: Harvard University Press.

Sleat, M. (2016). What Is a Political Value? Political Philosophy and Fidelity to Reality. Social Philosophy and Policy, 33(1-2), 252-272. 
Sleat, M. (Ed.). (2018). Politics Recovered: Realist Thought in Theory and Practice. New York: Columbia University Press.

Tomlin, P. (2012). Should We Be Utopophobes about Democracy in Particular? Political Studies Review, 10, 36-47.

Williams, B. (1997). Forward to Basics. In J. Franklin (Ed.), Equality (pp. 49-58). London: IPPR.

Williams, B. (2005). In the Beginning Was the Deed. (G. Hawthorn, Ed.) Princeton: Princeton University Press. 